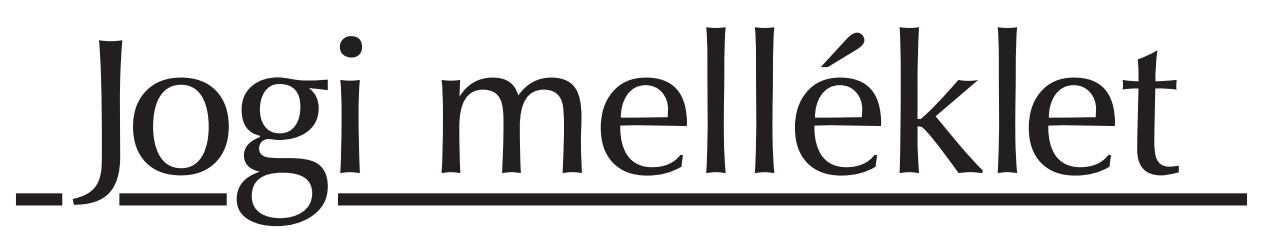

Külgazdaság, LXIV. évf., 2020. március-április (21-41. o.)

\title{
A kulturális javakkal kapcsolatos jogvitákra irányadó jog a magyar jogrendszerben
}

VADÁSZ VANDA

A tanulmány a jogellenesen külföldre vitt kulturális javakra vonatkozó kolliziós szabályozást mutatja be. Ennek során kitér a magyar jogforrási rendszer vizsgálatára, majd részletesen foglalkozik a Nemzetközi magánjogról szóló 2017. évi XXVIII. törvény egyes vonatkozó általános részi intézményeivel, illetve a kulturális javakra alkotott speciális kapcsolóelveivel.

Journal of Economic Literature (JEL) kód: K1.

\section{Bevezetés}

A nemzeti jogok szerepe a kulturális javak védelmében igen hangsúlyos. Ez a védelem - tárgyához illeszkedően - szükségképpen sokszínü: jogágakat átívelően manifesztálódik, hatékonysága a jogrendszer egészének harmonikus együttműködésén áll.

A kulturális javakkal kapcsolatos jogviták többségében megjelenik a nemzetközi elem. Ez a tárgyak jellegzetességeiböl adódik: hatalmas értékükből és könnyü mozgathatóságukból, valamint a nemzetközi kereskedelem sosem látott fellendüléséből fakadóan jellemzően határokon átívelő utat járnak be. Ez az út pedig bizonyos esetekben jogvitához vezet, melynek gócpontja a javak jogos tulajdonosának meghatározása. A jogrendszerek mechanizmusa pedig talán a lopott dolgon történő tulajdonszerzés szabályait illetően a leginkább megosztott, amely megosztottság - mint látni fogjuk - a kulturális javak védelmének ellenében hat.

https://doi.org/10.47630/KULG.2020.64.3-4.21

Vadász Vanda, tudományos segédmunkatárs, Jogtudományi Intézet. E-mail: vadasz.vanda@tk.mta.hu 
Előbbiekből eredően a nemzetközi magánjognak, a jogrendszerek kollíziós jogi szabályainak kiemelkedő szerepe van a kulturális javak védelme tekintetében. Az utaló módszert alkalmazva ugyanis egy kellőképpen érzékeny szabály képes arra, hogy úgy találja meg az adott ügyhöz legszorosabban kötődő jogot, hogy a jogvitában szereplő felek - akár ellentétes - érdekeit is kiegyensúlyozottan megjeleníti.

A tanulmány célja a kulturális javakra vonatkozó magyar kollíziós szabályozás vizsgálata és értékelése. Ennek érdekében számba vesszük a vonatkozó jogforrásokat, majd elvégezzük a 2018. január 1-jén hatályba lépett új Nemzetközi magánjogról szóló 2017. évi XXVIII. törvény (Kódex) bizonyos általános részi, illetve speciálisan a kulturális javak esetkörére alkotott szabályainak elemzését.

\section{Jogforrási rendszer}

A magyar jogrendszer kulturális javakra irányadó nemzetközi magánjogi szabályai különböző szintű jogforrásokban kapnak helyet. Legfőbb és legfontosabb belső jogforrásunk a Kódex. A Kódex azonban szubszidiárius jogforrás, ${ }^{1}$ azaz elsőbbséget enged mind a nemzetközi szerződésekben foglalt szabályoknak, mind az uniós normáknak. Először érdemes tehát ezeket áttekinteni.

\subsection{Nemzetközi eredetü jogforrások}

Leszükítik tehát a Kódex alkalmazási körét a jogforrási hierarchiában fölötte álló jogszabályok, mely normák a nemzetközi magánjogi szabályozás igen széles szeletét alkotják. Mint látni fogjuk, a dologi jogra vonatkozóan ez a kijelentés kevésbé igaz, mint a nemzetközi magánjog egyéb területeire, e jogági jellegzetesség azonban itt is tetten érhető.

A kulturális javak nemzetközi védelmére számos egyezmény jött létre. Ilyen az 1954-es Hágai Egyezmény, mely a kulturális javak fegyveres összeütközés esetén való védelme tárgyában kelt az ENSZ égisze alatt, ${ }^{2}$ illetve a kulturális javak jogtalan

${ }^{1}$ „E törvény rendelkezéseit olyan kérdésekben kell alkalmazni, amelyek nem tartoznak az Európai Unió általános hatályú, közvetlenül alkalmazandó jogi aktusa vagy nemzetközi szerződés hatálya alá." Kódex 2. §

2 Kihirdette az 1957. évi 14. törvényerejű rendelet, illetve Második Kiegészítő Jegyzőkönyvét a 2006. évi XXIX. törvény. Ez a jogforrás használta, illetve határozta meg elöször univerzális igénnyel, jogi kontextusban a „kulturális javak” kifejezést (Prott-O'Keefe, 1992, 312. o.). 
behozatalának, kivitelének és tulajdona jogtalan átruházásának megakadályozását és megelőzését szolgáló eszközökről szóló 1970. évi ENSZ Egyezmény ${ }^{3}$ is. Ezek a normák a kulturális javak védelmének fontos elemét adják; elég, ha az általuk tisztázott fogalmakra ${ }^{4}$ vagy a létrejöttükkel megszülető nemzetközi együttmüködésre gondolunk. Szintén lényeges a Nemzetközi Intézet a Magánjog Egységesítésére (UNIDROIT) által 1995-ben megalkotott, a lopott vagy jogellenesen külföldre vitt kulturális javakról szóló Egyezmény. ${ }^{5}$ A hatályát tekintve az a jogellenesen elvett (mind a lopott, mind az állami exportszabályozást megsértve külföldre vitt) kulturális javakra vonatkozóan állapít meg szabályokat, és a visszaszolgáltatást célzó perekben felmerülő olyan alapvető kérdéseket is szabályoz, mint az eljárás megindításnak időbeli határai, ${ }^{6}$ a jóhiszemủ vevő védelme, ${ }^{7}$ illetve az eljáró fórum megválasztása. ${ }^{8}$ Vizsgálódásunk körébe eső - kifejezetten kollíziós jogi - rendelkezéseket azonban ezek a források nem tartalmaznak.

Nemzetközi eredetü, 'puha jogi' - tehát kötő erővel nem rendelkező - eszköz a Nobel-békedíjas Institute of International Law szervezet ${ }^{9}$ gondozásában született Bázeli határozat ${ }^{10}$ amelyröl azonban mindenképpen említést kell tenni ebben a körben. Jelentőségét az adja, hogy egységesített jogeszközként kifejezett célja az állami jogalkotási munkálatok befolyásolása, illetve a bíróságok munkájának támogatása. ${ }^{11}$

A határozat rendeltetése szerint a kulturális örökség védelmét mozdítja elö, melyet a kulturális javak határokon átívelő adásvételének nemzetközi magánjogi vetületének szabályozásával végez. Saját hatályát széles körben határozza meg: azon adásvételekre ad modellszabályt, amelyekben az érintett kulturális javakat tulajdonosától ellopták, más módon jogellenesen vettek el, illetve, amelyekben e javakat az exportszabályok megsértésével vitték ki az adott ország területéröl. Ugyan a szövegben nem találunk erre kifejezett utalást, de érdemes leszögezni, hogy a forrás

${ }^{3}$ Kihirdette az 1979. évi 2. törvényerejü rendelet.

${ }^{4}$ Ilyen magának a „kulturális javaknak” a fogalma, illetve a származási állam fogalma.

5 Az Egyezményt a 2001. évi XXVIII. törvény hirdette ki.

${ }^{6}$ Lásd az Egyezmény 3. és 5. cikkét.

${ }^{7}$ Lásd az Egyezmény 4. és 6. cikkét.

${ }^{8}$ Lásd az Egyezmény 8. cikkét.

9 A szervezet célja a nemzetközi jog fejlődésének előmozdítása. Ennek érdekében kétévente tartandó ülésszakain határozatokat, állásfoglalásokat fogad el, melyek célközönsége a kormányzati szervek, nemzetközi szervezetek összessége, illetve a világ tudós közössége. Lásd: http://www.idi-iil.org/

${ }^{10}$ Lásd: Basel Resolution, 1991.

${ }^{11}$ Ez a funkció akkor aktiválódik fóként, amikor a bíróságoknak a nemzetközi normák alapján kell határozniuk olyan fogalmakat, mint a ,jó erkölcs”, vagy bizonyos kereskedelmi szokások tartalma (Jayme, 1997, 376. o.). 
az állam által érvényesítendő, jövőbeli tulajdoni igényekkel foglalkozik. ${ }^{12}$ Pontosabban olyan tulajdoni igényekkel, melyek tárgya az adott állam kulturális öröksége szempontjából jelentős kulturális javak köre. ${ }^{13}$ Az ilyen javakat érintő jogvitákban a mütárgy tulajdonjogának átruházására azon állam joga irányadó, amelynek az adott mütárgy a kulturális öröksége részét képezi. ${ }^{14}$ A határozat tehát a dologi jogi jogvitákra hagyományosan alkalmazandó lex situs szabályt elveti, és a szabályozási körben felmerülő érdekeket mérlegelve egy másik kapcsoló szabály, a származási ország joga - a lex originis - mellett teszi le voksát. A hangsúlyozott érdek pedig az - mint az a Preambulumban is olvasható -, hogy „,a műalkotás származási országában hatályos kulturális örökség védelmére irányuló intézkedéseket más országokban is elismerjék [...]". ${ }^{15}$

${ }^{12}$ Az időbeli hatályt illetően a forrás továbbá leszögezi, hogy a visszaható hatályú jogalkotást annak alkalmazásakor nem lehet figyelembe venni. A kitétel szükségességét a határozat megalkotását övező vitában felszólaló Mann a következőképp illusztrálta: „,[...] Úgy tűnik, az időbeli elemet nem veszi figyelembe a tervezet. Vajon csak a múltbéli helyzetek kezelésére alkalmazandó, vagy csak a jövőre nézve? A spanyol kormány ma elfogadhat egy olyan rendeletet, amely kimondja, hogy a jelenleg Spanyolországban található Goya-festményeket a kulturális örökség részének tekinti. Ebben az esetben a határozat minden bizonnyal alkalmazandó. De ha Spanyolország ma elfogadna egy olyan törvényt, amely deklarálja, hogy a Goya-festmények Spanyolországból történő kivitele 1900 januárja óta, visszamenőleges hatállyal illegálisnak nyilvánul, kell-e alkalmazni a határozatot erre a meglehetősen szélsőséges esetre is?" (Saját fordítás) (Institute of International Law: Yearbook, 1991, 290. o.)

${ }^{13}$ Shyllon felhívja a figyelmet arra, hogy nem kívánatos a „túlzó exportszabályozások” elterjedése. A kulturális nacionalizmus visszaszorítása érdekében történt a hatály ,,jelentős kulturális javak” körére történő redukálása. A szabályozás célja az, hogy a valóban jelentős nemzeti kincsek visszaszolgáltatását könnyítse, s nem az, hogy a túlburjánzó állami igényeknek teret engedjen (Shyllon, 2003, 517. o.).

${ }^{14}$ Lásd: Bázeli határozat, 2. cikk. Annak megállapítása során, hogy az adott tárgy az állam kulturális örökségének részét képezi-e, segítenek az állam által vezetett nyilvántartások (Institute of International Law: Yearbook, 1991, 305. o.).

${ }^{15}$ Érdemes megjegyezni - bár nem szigorúan kollíziós jogi kérdés -, hogy a jogeszköz a jóhiszemü vevő kérdéskörében is igyekszik iránytűként funkcionálni. Ennek érdekében a következő szabályokat fogalmazza meg. Jóhiszemúként határozza meg a tárgy birtokosát, ha az a tárgy megszerzésekor nem tudott, és észszerúen nem volt elvárható, hogy tudomása legyen a tárgy átadójának hibás jogcíméről, illetve arról, hogy a tárgyat a származási ország kiviteli szabályainak megsértésével exportálták (4. cikk 3. bekezdés). Ha a származási ország saját joga alapján a tulajdonjogot illetően nem történt változás (tehát a kulturális jószág jogszabályai alapján még mindig az állam tulajdonában van), a származási ország - észszerủ határidőn belül - igényelheti a tárgy visszaszolgáltatását. Ehhez bizonyítania kell, hogy „,az ilyen javak hiánya jelentősen befolyásolja kulturális örökségét” (4. cikk 1. bekezdés). Ha előbbi körülmények fennállnak, a jóhiszemủ vevő köteles a tárgyat visszaszolgáltatni. Jóhiszeműségének csak abból a szempontból van jelentősége, hogy a származási állam részéről ilyen minőségében méltányos kártalanítás illeti meg.

\section{JOGI MELLÉKLET • 2020/3-4}




\subsection{Európai uniós eredetü jogforrások}

A dologi jogi területet nem érintette mélyen az uniós jogalkotás sem. Az Európai Uniót alkotó nemzetek saját kulturális örökségének meghatározása és azok védelme is alapvetően tagállami hatáskörben maradt. Az Unió azonban igyekszik előmozdítani a tagállamok együttmüködését ezen a területen is - ha nem is annyira intenzíven, mint például a kötelmi vagy az öröklési jog terrénumán.

A kulturális javak Unión belüli visszaszolgáltatását koordinálni illetékes 2014/60/EU irányelv ${ }^{16}$ a tagállamok területéröl jogellenesen kiszállított kulturális tárgyak visszaszolgáltatásáról szóló 93/7/EGK irányelvet ${ }^{17}$ helyezte hatályon kívül. Az irányelv korrigálni hivatott elődje bizonyos rendelkezéseit: a hatályt kiterjesztve a „nemzeti kincs” fogalmát használja az adott állam által védendőként meghatározott kulturális javak összefoglalására, illetve a rendelkezések gyakorlatba történő átültetését megkönnyítő határidöket szab. ${ }^{18}$ Hatóköre kizárólag állami igényekre terjed ki, mégpedig olyan kulturális javak visszaszolgáltatását illetően, amelyeket 1993. január 1-jén vagy azt követően vittek ki jogellenesen az ország területéről. Az irányelv igen jelentős, hiszen a vindikációs igények elbírálásánál neuralgikus pontot jelentő kérdésekben is megnyilatkozik, ${ }^{19}$ egységes kollíziós szabályt azonban nem ad.

A 2019/880 rendelet ${ }^{20}$ a fenti szabályokat kiegészítendő, az Unió vámterületén kívül létrehozott vagy fellelt kulturális javakra vonatkozik. Hatályát a 2014/60/EU irányelvnél szúkebben határozza meg, abban az értelemben, hogy a védelem alá vont kulturális javaknál több - kor, illetve érték alapján érvényesülő - küszöböt is felállít. A rendelet célja a kulturális javak tiltott kereskedelmének akadályozása, melyet egységes vámeljárási, behozatali engedélyezési rendszer kialakításán keresztül kíván elérni. Kollíziós jogi szempontból figyelemre méltó rendelkezés a 4. cikk

${ }^{16}$ Lásd: Európai Parlament és a Tanács 2014/60/EU irányelve a tagállamok területéről jogellenesen kivitt kulturális javak visszaszolgáltatásáról és az 1024/2012/EU rendelet módosításáról.

${ }^{17}$ Lásd: Tanács 93/7/EGK irányelve a tagállamok területéről jogellenesen kiszállított kulturális tárgyak visszaszolgáltatásáról.

${ }^{18}$ A visszaszolgáltatási eljárás megindítására az irányelv hároméves határidőt állapít meg. A határidő azon a napon kezdődik, amikor a tagállamnak a központi hatósága tudomást szerez a kulturális tárgy hollétéről és annak birtokosáról. A jogvesztő határidő az irányelv értelmében harminc, kivételes esetben hetvenöt év.

19 A jóhiszemủ vevő kérdéskörét illetően az irányelv úgy rendelkezik, hogy a vásárlót kártalanítás illeti meg, amennyiben bizonyítani tudja, hogy kellő gondossággal és körültekintéssel járt el a tárgy megszerzésekor. A gondosság egységes mércéjének kialakítása érdekében pedig az irányelv olyan konkrét kritériumokat is megfogalmaz, mint a kifizetett vételár mértéke, a vevő vásárlást megelőző kutatásainak mélysége, illetve az engedélyek megléte.

${ }^{20}$ Lásd: Az Európai Parlament és a Tanács (EU) 2019/880 rendelete (2019. április 17.) a kulturális javak bejuttatásáról és behozataláról. 
4. pontja. A kulturális javak kivitelének jogszerüsége megállapításánál a rendelet azon ország szabályait tekinti relevánsnak, amelyben a kulturális javakat létrehozták vagy fellelték. „A jogszerü kereskedelem indokolatlan akadályozásának elkerülése érdekében", ${ }^{21}$ ha nem állapítható meg, hogy a kulturális javakat hol hozták létre, illetve azokat hol lelték fel (vagy 1972. április 24-e elött kivitték abból az országból, ahol azokat létrehozták vagy fellelték), ${ }^{22}$ azon ország rendelkezéseit kell figyelembe venni, ahol a javak öt évnél hosszabb időszakon keresztül tartózkodtak.

Ez az előírás iránymutató lehet a származási állam - sokszor igen problémás meghatározását illetően, illetve az „elárvult javak” ${ }^{23}$ helyzetének rendezése terén. A szabály kijátszását nehezítendő, a norma a fekvési hely kisegítő szabályához egy olyan feltételt kapcsol, mely megkövetel egy ötéves időtartamot a tárgyak és az ország kapcsolatában.

Figyelemmel kell lenni arra, hogy a kollíziós szabály rendeltetése csupán az, hogy a kivitel jogszerüségének megállapítására alkalmazandó jogot meghatározza. Hatókörén kívül esik tehát a tulajdoni igények elbírálása. ${ }^{24}$ Konkrét választ ad ugyanakkor egy fontos minősítési kérdésre - amikor lehetséges, a lex originis alkalmazását szorgalmazva.

\subsection{A Kódex hatálya}

Belső nemzetközi magánjogi törvényünk hatálya kiterjed minden olyan ügyre, amelyre a fenti instrumentumok nem tartalmaznak rendelkezést. Ha a kulturális javak ügyét rendező kollíziós jogot vizsgáljuk, ez egy rendkívül széles kör. Ugyanis, mint láthattuk, kötő erővel rendelkező külső jogforrás csupán a kérdés egyes marginális elemeire tér ki; egységes, univerzális igényü kollíziós szabály mindeddig nem került megfogalmazásra sem nemzetközi, sem uniós szinten.

Ha a magyar fórumnak a kulturális javak visszaszolgáltatásával kapcsolatos perben az irányadó jogot kell meghatároznia, a múveletet a Kódex szabályai alapján végzi el. Szükséges tehát megvizsgálni, mely általános és különös részi szabályok befolyásolják az alkalmazandó jog meghatározását.

${ }^{21}$ Lásd: Rendelet (8) preambulumbekezdése.

${ }^{22}$ Az 1970. évi UNESCO Egyezmény hatálybalépésének dátuma. A rendelet nagyban támaszkodik az Egyezményre, lásd a rendelet (7)-(9) preambulumbekezdését.

${ }^{23}$ Bizonyos esetekben a mütárgy rongálódása, a feltárása óta eltelt hosszú idő, vagy egyéb körülmények miatt egyáltalán nem állapítható meg a származási ország.

${ }^{24}$ A 4. cikk 3. pontja leszögezi, hogy a szabály alapján kiállított behozatali engedély nem értelmezhető az érintett kulturális javak legális eredetének vagy tulajdonjogának bizonyítékaként. 


\section{A Kódex általános részi intézményei}

A nemzetközi magánjog tudománya általános részi intézményeknek nevezi azokat a szabályokat, melyek a konkrét nemzetközi magánjogi szabályok alkalmazásával kapcsolatban adnak egységes iránymutatást. A törvénykönyvekben megjelenő általános rendelkezések országonként eltérnek, ${ }^{25}$ ezek pontos körének meghatározása kodifikátori feladat. A Kódex változtatott a Nemzetközi magánjogról szóló 1979. évi 13. törvényerejü rendeletben (régi Kódex) foglalt általános részi intézmények összetételén. ${ }^{26} \mathrm{~A}$ következőkben kiemelünk néhány szabályt a Kódex rendelkezéseinek köréből, amelyek a dologi jog e speciális területére alkotott egyedi kollíziós norma müködését nagyban befolyásolják.

\subsection{Minösités}

Amikor a bíróság nemzetközi elemmel rendelkezö jogvitában dönt, el kell végeznie a minősítés feladatát. A Kódex 4. § (1) bekezdése alapján a minősítést föszabály szerint ,a magyar jog fogalomrendszere” alapján kell elvégezni. A világ nemzetközi magánjogi szabályai osztoznak eme nézőpontban, a minősítés általában a lex fori alapján történik. ${ }^{27}$

A jogellenesen kivitt kulturális javak visszaszolgáltatása érdekében indított eljárás esetén a bíróság elé minősítési kérdések sora érkezik. Először is minősítenie kell az eljárás tárgyát, pontosabban meg kell határoznia, hogy az olyan dolog-e, melyet egy állam kulturális javai közé tartozónak tekint. Ez a joggyakorlatban komoly kihívásként jelenthet meg, ha arra gondolunk, hogy az egyes külföldi jogok kulturális javakkal, illetve magával a 'dologgal' kapcsolatos koncepciója a hazaitól igen eltérően alakul.

${ }^{25}$ Lásd: Burián [2014], 8-10. o.

${ }^{26}$ Burián László, illetve Szabó Sarolta kitűnő munkáikban elemzik; lásd: Burián [2018]; Szabó [2018].

${ }^{27}$ Egyes jogrendszerek azonban sajátosan rendezik ezt a kérdést, ha kulturális javakkal kapcsolatos jogvitáról van szó. Az angol bíróságok például alkalmazzák a fekvés jogának kivételét, ha a dolog ingónak, illetve ingatlannak minősítése terén adódik minősítési kérdés. A bíróságok ilyen esetben tehát a lex situs szabályait veszik alapul. Ez a megoldás valójában a kulturális örökség védelmének egy különleges eszköze. Az angol - és a francia - jog ugyanis védelmet biztosít az - ingatlannak minősülö - kulturális javakról elszakított részeknek is. Ezek a részek továbbra is a fődolog sorsát osztják, így ingatlannak minősülnek a hazai szabályok alapján, s a kereskedelmi forgalomban is az ingatlanoknak járó védelem illeti őket. Ezzel a módszerrel érvényre jut a külföldi állam örökségvédelmi rendelkezése. Lásd: Reddy [2001], 205. o. 
Ugyanis, mint ismeretes, a dolog fogalma alá a magyar jog hagyományosan a birtokba vehető testi tárgyakat vonja, mely álláspont - az absztrakció határait feszegető kihívások ellenére ${ }^{28}$ - az új, Polgári törvénykönyvről szóló 2013. évi V. törvény (Ptk.) megalkotása során is tartotta magát. ${ }^{29}$ Hasonló értelmezéssel találkozunk a svájci, a német és a holland törvénykönyvekben. A tulajdon tárgyának szélesebb felfogása érvényesül azonban az osztrák vagy a francia jogban, melyek a dolog fogalmát a jogokra is kiterjesztik. ${ }^{30} \mathrm{Az}$ angolszász jogrendszerekre kevésbé jellemző a pontosan körülhatárolt, egységes fogalmak megalkotása, ${ }^{31} \mathrm{~s}$ ez megmutatkozik a common law dologi jogi rendszerén is: dolog tulajdonképpen minden, ami forgalomképes, így a dolog szük értelemben vett kategóriáján túl ide tartoznak jogok, követelések, részesedések is. ${ }^{32,33}$

A kulturális javak fogalmát illetően szintén nagy a diverzitás. Ha közös pontot keresünk, a 140 részes állammal büszkélkedhető UNESCO Egyezmény meghatározását tekinthetjük kiindulási alapnak, azonban még a külső jogforrásaink sem követik következetesen ezt a definíciót; ${ }^{34}$ az a szabályozás célja és a hatály függvényében változhat. ${ }^{35}$ További nehézséget okozhat, hogy civil jogi rendszerek általában kü-

${ }^{28}$ Lásd: Serák [2007].

29 „A Koncepció és Tematika felveti ugyan a tulajdonjog dologtárgyúsága lazításának lehetőségét, ez azonban inkább a tulajdonjognak jogokra való kiterjesztését, semmint az »egy tulajdoni tárgy - egy tulajdoni jogviszony« elv áttörését jelentené.” Lásd: Kisfaludi [2006], 30. o.

${ }^{30}$ Lásd: Menyhárd [2002], 9. o.

31 A dolog fogalmának fejlődéséről a common law rendszerben lásd: Rotherham [1998].

32 Lásd: Menyhárd [2013], 30-31. o.

${ }^{33}$ Ennek fényében érdemes pár szót ejteni a Strehlow-gyűjtemény esetéről, mely érdekes minősítési kérdéseket vet fel. Strehlow - német antropológus, gyüjtő - gyermekként lelkész édesapjával együtt részt vett egy közép-ausztráliai misszióban, ahol így már gyerekként elsajátította az ausztráliai bennszülött törzsek nyelvét, belelátott szokásaikba, amely nagy hatást tett rá. Később már antropológusként tért vissza az általa megismert törzshöz, hagyományaik dokumentálása céljából. Az így született dokumentáció részét képezik a bennszülöttek titkos szertartásairól szóló filmek, hanganyagok és leírások is. A törzs tagjai annak idején azzal a feltétellel egyeztek bele mindezen anyagok rögzítésébe, hogy azokat Strehlow soha nem mutatja meg más fehér embernek - különösen nőknek, melyet a törzsi jog kifejezetten tilt. A probléma akkor merült fel, amikor, évtizedekkel később, Strehlow megjelentetett egy cikket egy német lapban a törzs titkos szertartásairól, a szöveget pedig a törzs tagjairól készült képekkel illusztrálta. A másodközlés jogát egy ausztrál lapnak adta el. A bennszülöttek jogaiért harcoló aktivisták követelése szerint a teljes anyagot vissza kell szolgáltatni azok ,,jogos tulajdonosának” (Prott-O'Keefe, 1992, 315. o.).

34 Lásd a 2014/60/EU irányelv elemzésénél írtakat.

35 „[A kulturális javakra vonatkozó szabályozások m]ás módon határozzák meg a védelem tárgyát is: belesorolva vagy kihagyva a közgyüjteményi illetve a magántulajdonú mütárgyakat, kortól vagy értéktől függően (vagy függetlenül). Ugyancsak különböző az ide tartozó mütárgyak hivatalos nyilvántartása: sok esetben egyáltalán nem vagy csak részleges nyilvántartás áll rendelkezésre. Az állam elővásárlási jogának megléte és szabályozása, illetve a kártérítési felelősség megállapítása is más és más módon történik. [...]” Lásd: Buzinkay [2003], 2. o.

\section{JOGI MELLÉKLET • 2020/3-4}


lönbséget tesznek azon javak védelme közt, melyek az államhoz tartoznak, és azok közt, amelyek tulajdonosa magánszemély. Bizonyos államokban más a jogállása a vallási szervezetek által kézben tartott javaknak is, mely különbségek szintén minősítési nehézségekhez vezethetnek. ${ }^{36}$

A kulturális javakkal kapcsolatban hangsúlyosan jelentkező absztrakciós különbözőségek feloldásában nagy szerepe lehet a Kódex 4. § (3) bekezdésének, mely olyan jogintézmények minősítésére vonatkozik, melyek a magyar jogban nem ismeretlenek, de funkciójuk vagy céljuk eltér attól, amit azok a külföldi jogban betöltenek. Ezekben az esetekben a bíróságnak a hozzáigazítás intézményét kell alkalmaznia és az adott eset sajátosságaira, valamint a külföldi jogra is figyelemmel kell az alkalmazandó jog megtalálása előtt a külföldi jogintézményt minősítenie.

A tovább- és visszautalás szabályozása jelentős mértékben megváltozott a Kódex születésével. A régi Kódex „felemás” szabályt alkalmazva teret engedett a külföldi jog kollíziós szabálya alkalmazásának, ha az visszautalt a magyar jogra, de nem vette figyelembe azt, ha az egy másik jogra utalt tovább. ${ }^{37}$ Eme megoldás folytán a renvoi előírása a kulturális javak visszaszolgáltatására irányuló perek során is módosíthatta a különös szabályok által meghatározott anyagi jogot, főleg, ha számításba vesszük, hogy az egyes államok jellemzően azonos tényállásra igen különböző kapcsoló elveket alkalmaznak. Végeredményben a régi Kódex alapján a lex fori szélesebb körben nyerhetett alkalmazást.

A hatályos szabályok szerint a renvoi vizsgálata abban az esetben végzendő el, amikor az alkalmazandó joghoz az állampolgárság kapcsoló elvén keresztül jutunk el, ${ }^{38}$ tehát újítás, hogy a kulturális javak tulajdonjogát érintő jogvitákban a renvoi kérdése a jövőben nem merül fel. ${ }^{39}$

${ }^{36}$ Lásd: Prott-O’Keefe [1992], 315. o.

${ }^{37}$ Ez a megoldás kevésbé a nemzetközi döntési harmóniát, mint a hazafelé törekvést szolgálja, így üdvözlendő, hogy az új törvény felülvizsgálta azt.

38 A szabály mögött húzódó indokokat lásd: Burián [2016], 37-39. o.

${ }^{39}$ Hasonló irányba mozdult el a kulturális javakat érintő jogvitákban gazdag angol esetjog is. A nagy hatású Berend-ügyben (The Islamic Republic of Iran v. Denyse Berend) a legfelsőbb bíróságnak egy időszámításunk előtti ötödik századból, Perszepolisz városából származó mészkő dombormú ügyében kellett döntenie. A dombormű Nagy Sándor hódításának időpontjától az 1930-as feltáró ásatásokig a földben hevert eltemetve. A két peres fél egyrészt az Iráni Iszlám Köztársaság, mely kulturális öröksége részeként igényt formált a tárgy tulajdonjogára, másrészt Denyse Berend, akinek a képvise- 
A Kódex által bevezetett egyik újdonság az akarati autonómia, a felek részére nyújtott jogválasztás lehetőségének szignifikáns kiterjesztése. A jogalkotó a praktikusság jegyében a jogintézmény bizonyos vonatkozásait az általános szabályok között helyezte el,$^{40}$ melyek a különös részben foglaltakkal együtt értelmezendők.

A kulturális javakat illetően a Kódex által szabályozott mindkét vonatkozó esetkörben lehetőség nyílik a korlátozott jogválasztásra. Ez a lehetőség azonban érthető módon nem a klasszikus értelemben vett - a szerződéses jogból ismert - korlátlan és hallgatólagosan is megtehetö ${ }^{41}$ jogválasztást hivatott biztosítani. A norma célja, hogy az egyes államok nem tulajdonostól történő tulajdonszerzést végletesen különböző módon szabályozó anyagi jogi szabályai ${ }^{42}$ közül arra mutasson, az kerülhessen alkalmazásra, amely a kulturális jószág védelmét adott esetben a leghatékonyabban szolgálja - a jogvitában szereplő, különböző oldalon álló felek érdekeinek figyelembevétele mellett. A feltételhez kötött jogválasztás eszközének alkalmazása ebben az esetben egy igen haladó és kreatív megoldás.

lője 1974-ben vásárolta meg a domborművet egy New York-i árverésen, majd azonos év novemberben leszállította azt számára, párizsi lakcímére. Berend érvelése szerint a francia jognak megfelelően jóhiszemű vevőként már 1974-ben megszerezte a tárgy tulajdonjogát, de ha a bíróság másképpen látja is, az 2004-ben, a harmincéves elbirtoklási idő lejártakor az minden kétséget kizáróan a tulajdonába került. Berend 2005-ben a londoni Christie's aukciósházon keresztül kívánta értékesíteni a mútárgyat, amikor is Irán bírósághoz fordult annak visszaszerzése érdekében.

Az angol jog alapján az ingókra alkalmazandó jog a lex situs, a francia jog, amelynek rendelkezései alapján Berend valóban tulajdonosi pozícióba került. Irán azonban azt kérte a bíróságtól, hogy alkalmazza a renvoi-t, és a továbbutalás tekintetbevételével a jogcím megszerzésének kérdésében az iráni jog alapján döntsön. A kérelem a továbbutalást nem a francia kollíziós jog egy bizonyos rendelkezésére, hanem Franciaország kulturális örökség védelmében tett nemzetközi elköteleződésére, az általa aláírt nemzetközi egyezmények szellemiségének figyelembevételére alapította (Forsyth, 2009, 139. o.) Irán érvelése szerint, ha az ügy a francia bíróság előtt zajlana, a francia bíró előbbiek alapján megállapítaná a lex situs alóli kivételt, és elfogadná az utalást az iráni jogra, mely szerint Irán visszakaphatja a dombormúvet. A nemzetközi döntési harmónia így megkívánja a renvoi alkalmazását.

Az eset abból a szempontból meghatározó, hogy a bíróság az adott ügyre vonatkozóan, a renvoi fennálltának elutasítása mellett precedenst teremtett a vissza- és továbbutalás ingók tulajdonjogáért folyó jogviták során történő figyelembevételének tekintetében. Az ügyben eljáró Eady bíró a következőképp fogalmazott: „A következetesség és jogbiztonság fenntartása érdekében az angol jog hosszú ideje úgy tartja, hogy ha az ingó dolog tulajdonosának jogcíme kérdéses, azt a lex situs alapján kell megítélni, mely a vitatott jogcím megszerzésének időpontjában értendő. [...] Nem látom okát [a renvoi doktrínája bevezetésének] az ingó tárgyak jelen ügyben vitatott kontextusában sem”. (The Islamic Republic of Iran v. Denyse Berend, [2007] EWHC 132 (QB), Case No: HQ05X01103, 23. pont)

${ }^{40}$ Kódex 9. §.

${ }^{41}$ A dologi jogi jogválasztásnak minden esetben kifejezettnek kell lennie. Kódex 9. § (1) a) pont.

${ }^{42}$ Az egyes belső jogszabályok elemzését lásd: Vadász (megjelenés alatt). 


\section{4. Általános kitérítö klauzula}

Az általános kitérítő klauzula, mint a neve is jelzi, a Kódex egészére nézve hatályos szabályként funkcionál, így az a dologi jogi részre tekintve is irányadó. A záradék megalkotásának szükségességét abból a premisszából eredeztethetjük, hogy a tipikus élethelyzetekre, általános jogi tényállásokra szabott kollíziós szabályok nem minden esetben mutatnak a „leghelyesebb” jogra. Szabó Sarolta szabatos megfogalmazása szerint „,[a] jogintézmény célja, hogy korrigálja a nemzetközi magánjogi szabályok téves kapcsolását, azaz azt a helyzetet, ha [...] egy harmadik állam jogával az adott jogviszony szorosabb kapcsolatot mutat". ${ }^{43}$ Kiemelendő, hogy a klauzula felhívása mindenképpen kivételes esetet feltételez. A kitétel megalkotásának ugyanis semmiképpen nem célja a „hazafelé törekvés” jelenségének támogatása. Kitűnően alkalmas ugyanakkor a Kódex által - az elődjétől eltérően - nem szabályozott csalárd kapcsolás megelőzésére. ${ }^{44}$

A klauzula számos nemzetközi magánjogi kodifikációban megjelent már, ${ }^{45}$ azonban ha speciálisan a kulturális javakat védő kollíziós szabályokra gondolunk, az amerikai jogfejlődéssel összevetve az elv alkalmazhatósága különleges jelentőséget mutat: ${ }^{46}$ az itt megjelenő trend alapján ugyanis a hagyományos kapcsoló faktorok egyre inkább veszítenek jelentőségükből a bírói mérlegelésnek nagyobb teret adó ún. „érdekeltség-központú” elvek javára. ${ }^{47}$

${ }^{43}$ Lásd: Szabó [2018], 456. o.

${ }^{44}$ Lásd: Ziegler-Vadász-Szabó [2017/2018.], 346. o.

${ }^{45}$ Lásd: Vékás [2016], 29. o.

${ }^{46}$ A jogellenesen külföldre vitt kulturális javak visszaszolgáltatásának az Egyesült Államokban különösen széles körủ bírósági gyakorlata van, mivel az lehetővé teszi a külföldi szuverénnel szembeni eljárást. (Az állami joghatósági immunitási kérdésekről lásd: Szabó, 2014) A kollíziós szabályokat illető változás úgy fogalmazható meg, hogy a lex situs mechanikus alkalmazása módosul - a tárgyban irányadó Second Restatement úgy rendelkezik, hogy a jogvitára azon állam szabályai alkalmazandók, amelyek az ügy körülményeire tekintettel a legszorosabb kapcsolat füzi a felekhez, a jogvita tárgyához és annak átruházásához (Frey, 2012, 1069. o.) A bírósági gyakorlat értelmezésében a szabály célja, hogy ne automatikusan egy adott földrajzi ponthoz kösse az ügyet, hanem lehetőséget adjon arra, hogy az egyes nemzeti szabályok mögött álló törvényhozói szándék is érvényre kerülhessen. Ez egy tartalmi vizsgálódást feltételez, amelynek során az eset körülményein kívül a bíróságnak meg kell vizsgálnia, hogy az ügyhöz kötődő, szóba jövő nemzeti jogok alkalmazása milyen eredménnyel járna az érintett jogrendszerre nézve; például elősegítené-e a kulturális javak országba történő beáramlását, elrettentené-e a saját állampolgárokat a lopott javak vételétől, garantálja-e a forgalom biztonságát.

47 A fejlődés ívét a következő ügyek adják meg: Kunstsammlungen Zu Weimar v. Elicofon, 678 F.2d 1150 (2d Cir. 1982); Greek Orthodox Patriarchate v. Christie's, Inc., No. 98 Civ. 7664, (S.D.N.Y. 1999); Schoeps v. Museum of Modern Art, 594 F. Supp. 2d 461 (S.D.N.Y. 2009); Bakalar v. Vavra 619 F.3d 136 (2d Cir. 2010). 
Az általános kitérítő klauzula funkciója semmiképpen sem az, hogy a kulturális javakkal kapcsolatos restitúciós perekben mindig felhívásra kerüljön - ez ellentétben állna a generálklauzula kivételes jellegével. Annál is inkább, mivel az amerikai kollíziós szabályok módosulása leginkább annak tudható be, hogy a kulturális javak körül forgó jogviták - a többi ingóhoz képest - speciális körülményei nem kapnak figyelmet a jogalkotó részéről. A Kódex e javak helyzetére szabott különös kollíziós szabályokat hozott létre. A klauzula felhívhatósága azonban egyes összetett tényállásoknál kiemelkedően rugalmas jogszabályi környezetet teremt a bíróság részére. ${ }^{48}$

\subsection{Statútumváltás}

Különös jelentősége van a statútumváltás szabályainak a kulturális javakkal kapcsolatos esetekben, mivel ezek az ingók jellemzően sokat „,ándorolnak” - tekintet nélkül az országhatárokra.

A Kódex 14. szakaszában átfogó jelleggel úgy rendelkezik, hogy az alkalmazandó jogot meghatározó körülmények megváltozásának nincsen visszaható hatálya. Az ingó dolgokra vonatkozóan azonban kivételszabályt tartalmaz a 41. szakasz, mely alapján, ha a jószág tartósan egy másik állam területére kerül, a szerzett jogok ezen ország szabályai szerint ismerhetők el. ${ }^{49}$

Az elbirtoklást illetően is hasonló rendelkezést tartalmaz a Kódex: azon állam joga szerint kell azt megállapítani, ahol a tárgy az elbirtoklási idő lejártakor volt. Az egyes államok eltérő követelményeket állítanak az elbirtoklás megállapításához, mind az időbeli, mind az egyéb feltételek vonatkozásában. Míg a magyar polgári jog nem kíván meg heterogén feltételeket az egyéb ingókhoz képest, ${ }^{50}$ a speciálisan kulturális javak mozgását szabályozó 2005 -ös svájci törvény ${ }^{51}$ például az állam által regisztrált, kiemelkedően fontosnak minősített kulturális javak tekintetében kimondja, hogy ezen javakat nem lehet elbirtokolni, az egyéb kulturális javak tekintetében pedig az elbirtoklási időt harminc évre emelte. ${ }^{52}$ Egyes államok jogrendszere

48 A szabály hatékonyságát sajnálatos módon nagyban csökkenti a törvényben az alkalmazásra elöírt, igen szűkös időbeli korlát. Lásd a Kódex 10. § (1) bekezdését.

49 A rendelkezés arra hivatott, hogy a korábbi és későbbi fekvési hely dologi jogi rendszerét összeigazítsa, hiszen a dologi jogok zárt rendszere maga után vonja azt a következményt, hogy az ingó dolog fekvési helyének megváltozása adott esetben a dologi jog tartalmát is megváltoztatja.

50 „Elbirtoklás útján megszerzi a dolog tulajdonjogát, aki a dolgot ingatlan esetén tizenöt, ingó dolog esetén tíz éven át sajátjaként szakadatlanul birtokolja.” Ptk. 5:44. § (1) bekezdés.

51 Lásd: Cultural Property Transfer Act.

52 Lásd: Weber [2006], 103. o.

\section{JOGI MELLÉKLET • 2020/3-4}


a jóhiszeműséget az elbirtoklás feltételéül szabja: Olaszországban a tárgy jóhiszemü birtokosa tíz év után tulajdont szerez, egyébként az elbirtoklási idő húsz év; míg mások ilyen követelményt nem támasztanak: a francia jog csupán ötéves elbirtoklási időt ír elő. ${ }^{53}$ Így érthetően nélkülözhetetlen volt, hogy a Kódex e kérdés tekintetében állást foglaljon.

Fontos az a kitétel is, mely szerint az elbirtoklást a dolog fekvési helyének megváltozása nem szakítja meg. ${ }^{54} \mathrm{Az}$ elbirtoklás szempontjából tehát a statútumváltás általános szabálya irányadó, mely rendelkezés a forgalom biztonságát hivatott garantálni.

\section{A különös részi szabályok}

A kulturális javakkal kapcsolatos kollíziós szabályozásról alapvetően elmondható, hogy az két kapcsolóelv köré épül. A hagyományos utat a lex situs rendelése jelenti. Egyes államok, illetve nemzetközi jogforrások azonban felismerve a kapcsolóelv kulturális javakat érintő jogvitákban mutatott korlátozott hatékonyságát, a lex originis szabályának bevezetése mellett döntöttek, illetve azt szorgalmazzák. A következőkben az egyes megoldások jellemzőit, majd a Kódex megoldását vesszük górcső alá.

\subsection{Kapcsolóelvek a jogellenesen elvett kulturális javakkal kapcsolatos}

jogvitákban

A lex situs rendelése az ingókkal kapcsolatos jogviták területén tehát a mai napig meghatározó, tradicionális megoldása a kollíziós dologi jognak. Az elv müködése alapján azon állam joga alkalmazandó, amely államban a tárgy a releváns időpontban tartózkodott. A dolog fekvésének helye ténykérdés: azon fizikai helyet jelöli, ahol a dolog található. ${ }^{55}$

Elvitathatatlan elönye a lex situs szabálynak, hogy egyfajta nemzetközi udvariasságot jelent, ha a jogügylet helye szerinti jog kerül alkalmazásra. Ezzel azon szuverén joga lesz illetékes a jogvitát elrendezni, mely alapján az eredeti jogügylet

${ }^{53}$ Lásd: Saltarelli [2018], 146-147. o.

${ }^{54}$ Lásd: Kódex 41. § (4).

${ }^{55}$ Lásd: Csehi [2019], 7. o. 
bonyolódott. ${ }^{56}$ A lex rei sitae melletti érvként szokás továbbá felhozni, hogy az könynyen meghatározható, így alkalmazása tiszta helyzetet teremt. Az ügyletben szereplő felek számára egy esetleges jogvita esetén a kollíziós szabályt felhívva egyértelmü, hogy azon ország joga lesz alkalmazandó, ahol a mütárgy vásárlása végbe ment. Aki tehát idegen államban vásárol mütárgyat, előre számolhat azzal, hogy vitás kérdés esetén a vásárlás helye szerinti jog lesz irányadó. Logikusan következik az elv nagy előnyéből annak hátránya is: az alkalmazandó jog alakulásának manipulálhatósága. Hiszen, ha a lex situs szabály a maga nyersességében alkalmazásra kerül, tekintet nélkül minden kapcsolódó érdekre, felütheti a fejét egy olyan káros trend, mely az 'engedékenyebb’ dologi jogi szabályozást alkalmazó államok felé tereli a tisztázatlan eredettel eladni kívánt tárgyakat. Az ilyen államok így a jogellenesen szerzett mütárgyak feletti jogcím tisztára mosásának népszerü helyszíneivé válhatnak. ${ }^{57}$

Az elv viszonylag egyszerű megfogalmazhatósága mögött összetett kérdések sora húzódik. ${ }^{58}$ Kezdve a releváns időpont kérdésével: a jogvitákban érintett mütárgyak jellegzetes módon az átruházások egész sorában érintettek - mely átruházás legyen akkor az irányadó? A lex rei sitae az adott jogrendszer értelmezésének függvényében lehet az utolsó ügylet helye - mint a New York-i jogban -, de jelentheti azt az államot is, amelyben a tárgy a jogvita időpontjában fekszik - ilyen a francia jog

56 Lásd: Frey [2012], 1068. o.

${ }^{57}$ Mindez a jogalkalmazó számára is nyilvánvalóvá vált, amit kitűnően prezentál a Bakalar- v. Vavra-ügy (Bakalar v. Vavra 619 F.3d 136 (2d Cir. 2010)). Az ügy apropója Schiele „Sitzende angezogenem linken bein (Torso)" címet viselö festménye volt. Az alkotás a második világháború előtt a Grunbaum család gyüjteményének részét képezte. A háborús események a festmény útját visszakövethetetlenné tették; ami biztos azonban, hogy az 1956-ban került Ausztriából Svájcba, adásvétel útján. Öt hónap után a tárgyat átszállították New Yorkba, amikor is egy helyi galéria megvásárolta azt. David Bakalar - gyüjtő - 1963-ban vette meg előbbitől a festményt. Bakalar 2005-ben úgy döntött, hogy értékesíteni fogja a mütárgyat, ennek során azonban eredettel kapcsolatos problémák merültek fel. A helyzet tisztázása érdekében Bakalar eljárást indított a New York-i bíróságon, melynek során azt kérte, a testület mondja ki, hogy a torzó tulajdonjogával ő rendelkezik. Az eljáráshoz az eredeti tulajdonos leszármazói is csatlakoztak, akik saját tulajdonjoguk megállapítását kérték. Az elsőfokú bíróság a lex situs szabályt hívta fel és a svájci jog alkalmazása mellett döntött - hiszen itt történt meg az a jogügylet, mely meghatározza a festmény további tranzakcióinak sorsát. A fellebbviteli fórum egyedülálló érveléssel változtatta meg ezt a döntést: a bíróság arra jutott, hogy Svájc kapcsolódása az ügyhöz csekély, hiszen az idő, amelyet a festmény itt töltött, csupán öt hónap. Érdemes megjegyezni, hogy a svájci jog a jóhiszemü vevőnek kedvez, míg a New York-i az eredeti tulajdonost helyezi előnyösebb helyzetbe. A New York-i kollíziós jog által biztosított lehetőséggel élve, azon érdek hangsúlyozásával került sor New York állam jogának alkalmazására, hogy az hasonló bírósági döntések nyomán ne váljék a lopott mủtárgyak piacává. A jóhiszemű vevő, Bakalar tulajdonjoga így végül nem kerülhetett tisztázásra.

58 Ennek oka legfőképpen egy közös jogforrás hiánya. Ugyanis annak ellenére, hogy az elv alkalmazása általánosnak mondható az ingók tekintetében, egyetlen nemzetközi eszköz sem igazít el az alkalmazás részleteinek tekintetében. Így minden nemzeti bíróság saját értelmezést dolgoz ki, melyek némiképp eltérnek egymástól. Lásd: Pecoraro [1990], 7. o.

\section{JOGI MELLÉKLET • 2020/3-4}


felfogása ${ }^{59}$ Logikus választ ad a kérdésre a magyar Kódex, amikor úgy rendelkezik az ingókkal kapcsolatos általános szabályoknál, az irányadó időpont a jogi hatást kiváltó tény létrejöttének időpontja. ${ }^{60} \mathrm{~A}$ kulturális javakkal kapcsolatban ez „a szerzés időpontjára utal, azaz az exportálás és a jogellenes határon átnyúló adásvétel”61 időpontjára. A lex situs szabály nagy előnyének tartott kiszámíthatóság és az előreláthatóság már ezen a ponton sérül. Előbbi tovább gyengül, ha annak müködését az eredeti tulajdonos szemszögéből nézzük: a mütárgyát elvesztett személy a legkevésbé sincs abban a helyzetben, hogy visszakövetelendő mütárgya későbbi fekvési helyére befolyással legyen, vagy egyáltalán azt meg tudja határozni. ${ }^{62}$

A lex rei sitae általános alkalmazásának különösen fájó hátránya a kulturális javakkal kapcsolatos jogviták tekintetében, hogy többnyire hatástalanná teszi azt a védelmet, amelyet a származási állam a mútárgy számára nyújt. A téma jeles kutatója, Symeon C. Symeonides megfogalmazásában, ,az, aki a származási hely államának joga szerint a tárgy tulajdonosának tekinthető, nem veszítheti el azt a védelmet, és azokat a jogorvoslati eszközöket, amelyeket ezen állam számára biztosít, csak azért, mert a dolog jelenleg egy másik országban található”." ${ }^{63,64}$

Előbbi fogyatékosságok kiküszöbölésére alkalmas a Bázeli határozat által is szorgalmazott lex originis szabály. A származási hely joga a következőt jelenti: a kulturális javakkal kapcsolatos jogok jóhiszemủ vásárlónak történő átruházásának érvényességét és hatását az eredeti tulajdonos joga határozza meg, mely a lopás időpontjában vizsgálandó. Az elv alkalmazása különösen azon típusú tényállások esetén tűnik helyesnek, amikor a kulturális tárgy kivitele a származási ország ex-

${ }^{59}$ Lásd: Reddy [2001], 211. o.

${ }^{60}$ Lásd: Kódex 39. § (2) bekezdés.

${ }^{61}$ Lásd: Szabó [2016], 164. o.

${ }^{62}$ Lásd: Reyhan [2001], 1040. o.

${ }^{63}$ Lásd: Symeonides [2005], 1186. o.

${ }^{64}$ Jól illusztrálja a visszásságot a Perui kormány kontra Johnson-ügy (Government of Peru v. Johnson, U.S. District Court for the Central District of California - 720 F. Supp. 810, C.D. Cal. 1989). Az eset tényállása szerint Peru nyolcvankilenc darab kora újkori arany-, kerámia- és textiltárgy viszszaadását kérte, melyet állítása szerint jogellenesen tártak fel az ország területén és ezt követően a kiviteli korlátozásokat megsértve vitték őket másik állam területére. Tulajdoni igényét a kincstalálásra vonatkozó saját szabályaira alapította, mely kimondta, hogy minden, állami területről származó történelmi tárgy az állam tulajdonát képezi. A kaliforniai bíróság Peru indítványát azzal az érvvel utasította vissza, hogy az nem tudja bizonyítani, hogy a tárgyakat az ő felségterületén ásták ki, valamint azt sem, hogy nem azelőtt ásták ki őket, hogy a fent említett szabályok hatályba léptek. Az exportkorlátozások végrehajtását pedig - mivel közjogi szabályok - más állam bírósága nem rendelheti el. A tárgyak viszszaszolgáltatására így nem került sor, azok magánkézben maradtak. (Elemzi: Fincham, 2008-2009, 117-118. o.) Az eset kimenetele nem mondható kirívónak - hasonló okokból nem ítélte meg a New York-i bíróság a Seuso-kincsek Magyarország részére történő visszaszolgáltatását sem. (Részletesen lásd: Vadász, 2017.) 
portszabályainak megsértésével történt. A kollíziós szabályoknak - amelyek célja az esethez legszorosabban kötődő jog megtalálása - itt nyilvánvalóan a származási államra kell mutatniuk, aminek következménye a javak visszaszolgáltatásának elrendelése lesz. A kapcsoló elv rigid alkalmazása azonban az alkotás jóhiszemü megszerzőjét - aki a forgalom biztonságában joggal bízhatott - sokszor védelem nélkül hagyja. A gyakorlati alkalmazás során továbbá problémaként jelentkezhet magának a származási helynek a beazonosítása is. A vonatkozó jogforrások ${ }^{65}$ és a jogirodalom igyekszik iránymutatást adni a dilemma feloldása érdekében ${ }^{66}-$ e kérdéskör jelenti mégis a szabály Achilles-sarkát. ${ }^{67}$

\subsection{A Kódex megoldása az állam által támasztott igények esetén}

A jogrendszereknek általában kész válaszuk van az ingók, esetleg magukkal a kulturális javakkal kapcsolatos nemzetközi magánjogi esetek kezelésére, és ezt a

${ }^{65}$ Az UNESCO Egyezmény felsorol bizonyos tényezőket, melyek alapján a származási ország meghatározandó. Ilyen összekötő faktorként kezeli az állampolgárságot, ha a kulturális jószágot létrehozó alkotó az állam területén hozta létre a tárgyat. Ha az állam területén létrejött alkotás létrehozói nem az adott állam állampolgárai, azt akkor is származási országnak kell tekinteni, amennyiben az alkotás ,az adott [á]llam számára fontos”. A találási hely szintén meghatározhatja a származási államot. Származási államnak nevezi az Egyezmény azon államokat is, melyek „,szabad megegyezésen alapuló csere" útján, ajándékként vagy a törvényes adásvétel módján jutottak a kulturális jószághoz. Az UNESCO Egyezményt kiegészítő UNIDROIT Egyezmény azt a feltételt szabja egy állam származási országként történő elismerése érdekében, hogy a számára „,kiemelkedően fontos” tárgyat a területéről vigyék ki, illetve a következő körülmények közül legalább egy fennálljon: a tárgy eltávolítása sérti a kulturális tárgy vagy környezete fizikai megóvását, egy komplex műtárgy integritását, tudományos vagy történelmi jellegủ információk megőrzését, illetve a tárgy hagyományok szerinti használatát.

A Bázeli határozat származási országot az 1. cikk b) pontjában úgy határozza meg, mint ,az az ország, amellyel az érintett tárgy kulturális szempontból a legszorosabb kapcsolatban van”. A határozat elfogadását megelőző vita során egy hozzászóló a következő példával szemléltette a problémát: „Ha egy Picasso kék korszakában alkotott képet egy harmadik állam területéről (mely nem Spanyolország, sem Franciaország) ellopnak, akkor Spanyolország, vagy Franciaország követelheti a festményt, mint a kulturális öröksége részét képző műalkotást?" (Saját fordítás. Institute of International Law: Yearbook, 1991, 290. o.) Felmerül a kérdés, hogy vajon a harmadik állam, melynek területéről a tárgyat ellopták, fellép-e hasonló követeléssel. Az erről szóló vita a határozat megalkotása során úgy konkludált, hogy lehetetlen minden felmerülő helyzetre szabályozást adni, azt az adott eset körülményeit figyelembe véve kell kezelni.

${ }^{66}$ Érdemes megemlíteni Müller elemzését, aki szerint ilyen lehet a múvész állampolgársága, mely a mütárgyat alkotta; a tárgy földrajzi tartózkodási helye; annak vallási jelentése egy adott csoport számára; illetve egy adott gyűjtemény részeként való elismertsége. Lásd: Müller [1998], 401. o.

${ }^{67}$ Nem elhanyagolható emellett az a - nem tisztán jogi - körülmény sem, hogy igen erős a múzeumi lobbi a kapcsolóelv bevezetése ellenében, mivel attól tartanak, a lex originis alkalmazásának elterjedése a gyűjtemények jelentős részének feladásával járna. Lásd: Bandle-Chechi-Renold [2012], 5. o.

\section{JOGI MELLÉKLET • 2020/3-4}


berögződött választ később igen nehéz átformálni. A Kódex merőben új és innovatív kollíziós szabályozást hozott létre kiemelten ezekre a tényállásokra.

A régi Kódex föszabályként a dolog fekvése helyén irányadó jogot rendelte alkalmazni, amelyet a jogi hatást kiváltó tény létrejöttének időpontjában kellett meghatározni. ${ }^{68} \mathrm{~A}$ jogszabály nem tett különbséget a kulturális javak és egyéb ingók közt, azokra egységesen a lex situs volt alkalmazandó. Ezáltal mondhatni a régi kollíziós szabályrendszer nem vette figyelembe a kulturális javak egyediségét, történelmi fontosságukból adódó és érzelmi értékét. Az új Kódex megalkotói, felismerve ezen jellegadó tulajdonságok fontosságát, az általános dologi jogi szabályok rögzítését követően helyezték el a kulturális javakra irányadó egyedi szabályokat.

A kulturális javak jogellenes kivitelének kétféle tényállását - amikor egy állam kiviteli szabályait megsértve viszik a tárgyakat más országba, illetve amikor egy magánszemélytől ellopott dolgot visznek ki az ország területéröl - a Kódex külön szakaszokban szabályozza. Az elkülönítés indokolt, hiszen az utaló norma mindkét esetben más érdekeket hivatott megjeleníteni. A 46. § rendezi az állam tulajdoni igényére vonatkozó szabályokat. A szakasz lehetővé teszi a jogválasztást a restitúciós igénnyel fellépő ország számára: választhatja saját, vagy annak a másik államnak a jogát, amelynek területén az adott dolog fekszik. A saját jog választása ebben az esetben értelemszerủen a lex originist jelenti. A norma megadja az államok számára a lehetőséget, hogy a történelmi helyszíneik és tárgyaik számára kialakított védelmet érvényesíteni tudják. A jelentős értékủ és rendkívül „mozgékony” kulturális javak olyan összetett tényállások létrejöttében is érintettek lehetnek, amikor a dologi jogi „főszabály”, a lex situs felhívása előnyösebb az állam számára, illetve szorosabb kötődést jelent ${ }^{69} \mathrm{~A}$ releváns időpont ebben az esetben a tulajdonjogi igény elbírálásának időpontja. A tipikusan egymást követő tranzakciók rengetegében a Kódex egy biztosan megállapítható időpontot rendel. Ennek további előnye, hogy gátat vet az árnyékpiac taktikájához tartozó azon jelenségnek, hogy a jogellenesen kivitt javakat a vevő számára kedvezőbb jogot elrendelő országba áramoltassák.

A paragrafus gondoskodik róla, hogy a jóhiszemü vevő is méltányos védelemben részesülhessen. Ha ugyanis a tulajdoni igényével fellépő állam a saját jogának

${ }^{68}$ Lásd: Régi Kódex 21. §-a. A főszabály tartalmilag megegyezik a Kódex 39. §-a által meghatározott általános szabállyal.

${ }^{69}$ A származási ország meghatározása, mint láthattuk, sokszor nem egyszerü. Egy tárgy a kivitel után asszimilálódhat új fekvési helye kultúrájába, így a kapcsolat a származási ország és a tárgy modern története között esetlegessé válik - adott esetben a fekvési hely és a mütárgy kötődése erősebbé válik. Lásd: Roodt [2015], 238. o. 
alkalmazását választja, amely nem nyújt védelmet a jóhiszemủ birtokosnak, utóbbi kérheti, hogy a bíróság a lex situst alkalmazza az ő helyzetének rendezése során.

A kollíziós szabály a kapcsoló elvek ezen kombinációjával kiküszöböli a nyers alkalmazásból adódó nehézségeket: a származási állam közjogi szabályai érvényesülhetnek, és a vitában szereplő mindkét „viszonylag ártatlan"70 fél védelmet kap.

\subsection{A Kódex megoldása a lopott dolgon történö tulajdonszerzés problémakörére}

Az eredeti tulajdonos és a jóhiszemü vevő helyzetét az egyes országok igen különbözően ítélik meg és szabályozzák. Általánosságban elmondható, hogy a common law rendszerek a kulturális javakat érintő jogvitában az eredeti tulajdonosnak kedveznek, míg a kontinentális rendszerek gyakran a jóhiszemü vevőt részesítik erősebb védelemben. Az angolszász jogrendszerek anyagi joga alapján ugyanis lopott dolgon tulajdont szerezni nem lehet, míg a civiljogi országok lehetőséget adnak erre, meghatározott feltételek fennállása esetén. ${ }^{71}$ Köztudott, hogy a hazai polgári jog is megadja ezt a lehetőséget a jóhiszemü vevőnek ${ }^{72}$ így az anyagi jogi szabályok alapján az eredeti tulajdonos könnyedén védelem nélkül maradhat a mütárgya viszszaszolgáltatását célzó küzdelemben. Az ő kezébe kíván adni a Kódex egy hatékony eszközt, amikor úgy rendelkezik, hogy ,[a]z eredeti tulajdonos birtokából jogellenesen kikerült dologra vonatkozó tulajdonjogi igényre az eredeti tulajdonos választása szerint annak az államnak a joga alkalmazandó, amelynek területén az eltűnése időpontjában a dolog volt, vagy amelynek területén a tulajdonjogi igény elbírálásának időpontjában a dolog van."’3

Az eredeti tulajdonos így a számára kedvezőbb jogot választhatja, mely döntést az esethez kapcsolódó jogok közül két opcióra korlátoz a törvény: a tulajdonos dönthet saját joga, illetve a lex situs mellett. Ezzel a Kódex védelmet biztosít az eredeti tulajdonos számára, ugyanakkor a belga mintára megalkotott szabály a dologi jogi kollíziós szabályozás terén unortodox megoldásával bizonyos szintủ jogi bizonyta-

${ }^{70}$ Lásd: Fincham [2008-2009], 150. o.

${ }^{71}$ Ez a differenciált hozzáállás az oka annak, hogy azonos tárgyat érintő jogvitában két különböző állam fórumától a legeltérőbb végeredményre lehet számítani, s ez a forum shopping jelenségét táplálja. A megelőzésben a kollíziós jog szerepe jelentős, hiszen az anyagi jogi szabályok közelítésével szemben egy egységes kollíziós jogi rendszer kidolgozása észszerü törekvés lehet.

${ }^{72}$ Lásd: Ptk. 5:39. §.

${ }^{73}$ Lásd: Kódex 47. § (1) bekezdés. 
lanságot is teremt. ${ }^{74}$ Hiszen a kereskedelmi forgalom biztonságának alapelvét nagyra tartó civiljogi rendszer pártfogásában bízó fél - a jóhiszemü vevő - helyzete bizonytalanabbá válik, még akkor is, ha a Kódex arra is figyelemmel van, hogy a választás szabadsága ne legyen olyan széles körü, hogy esetleg az esethez csak csekély szállal kapcsolódó ország joga kerülhessen alkalmazásra. Ennek ellensúlyozására került megalkotásra - a 46. § megoldásának mintájára - a szakasz második bekezdése, mely kimondja, hogy ha az eredeti tulajdonos saját jogát választotta, és az nem biztosít védelmet a jóhiszemủ birtokos részére, az igényelheti a kérdésre a lex situs alkalmazását.

\section{Végszó}

A jogirodalomban gyakran hangoztatott tétel, hogy a nemzeti kollíziós jogforrások súlyos hiányossága, hogy nem tartalmaznak speciálisan a kulturális javakra kifejlesztett normát, és ezáltal közvetetten támogatják e javakat érintő, hatalmas méreteket öltő nemzetközi feketekereskedelmet. ${ }^{75}$ A Kódex létrejöttével a magyar jogot többé hasonló kritika nem érheti, hiszen egy erős védelmi eszközt hozott létre eme különleges jelentőségủ javak megóvása érdekében. Az általános, illetve a különös részi szabályok harmóniájával a Kódexben egy olyan instrumentum került megalkotásra, mely rugalmasságával, illetve a sajátosan a kulturális javakat övező jogvitákban megjelenő érdekek érzékeny kiegyensúlyozásával példaértékủ lehet a tárgyakat érintő jövőbeli kodifikációk számára is.

\section{Felhasznált irodalom}

Bandle, Anne Laure - Chechi, Alessandro-Renold, Marc-André [2012]: Case Achaemenid Limestone Relief - Iran v. Berend. ArThemis Art-Law Center - University Of Geneva. Letölthető: https:// unige.ch/art-adr

Burián László [2014]: Kodifikálható-e az Európai Unió nemzetközi magánjogának „Általános Része”? Iustum Aequum Salutare, X. évf., 2. sz., 7-13. o.

Burián László [2016]: A vissza- és továbbutalás (renvoi). In: Berke Barna-Nemessányi Zoltán (szerk.): Az új nemzetközi magánjogi törvény alapjai. Kodifikációs előtanulmányok. HVG Orac, Budapest. Burián László [2018]: Általános részi jogintézmények szabályozása a régi és az új nemzetközi magánjogi Kódexben. Közjegyzők Közlönye, 3. évf., 3. sz.

${ }^{74}$ Lásd: Wantuch-Thole elemzését a belga nemzetközi magánjogi törvényröl (Wantuch-Thole, 2015, 251. o.)

${ }^{75}$ Lásd: Crowell [1992], 208. o. 
Buzinkay Péter [2003]: Mủtárgyvédelem és az Európai Unió. A kulturális javak védelme és Magyarország uniós csatlakozása. Müemlékvédelem: Kulturális Örökségvédelmi Folyóirat, XLVII. évf., 1. sz., 31-36. o.

Crowell, Deidre L. [1992]: Autocephalous Greek-Orthodox Church of Cyprus v. Goldberg \& (and) Feldman Fine Arts, Inc.: Choice of Law in the Protection of Cultural Property. Texas International Law Journal, Vol. 27., No. 1.

Csehi Zoltán [2019]: A dologi jog új kollíziós szabályai. Jogtudományi Közlöny, 74. évf., 1. sz.

Fincham, Derek [2008-2009]: How Adopting the Lex Originis Rule Can Impede the Flow of Illicit Cultural Property. The Columbia Journal of Law \& the Arts, Vol. 32., No. 1.

Forsyth, Christopher [2009]: A Modest Defence of Renvoi. Journal of South African Law, Vol. 2009., Issue 1., 135-141. o.

Frey, Laurie [2012]: Bakalar v. Vavra and the Art of Conflicts Analysis in New York: Framing a Choice of Law Approach for Moveable Property. Columbia Law Review, Vol. 112., 5. sz.

Institute of International Law [1991]: Yearbook. Vol. 64., Part II., Session of Basel 1991. Deliberations of the Institute during Plenary Meetings, Éditions A. Pedone, Paris.

Jayme, Erik [1997]: Protection of Cultural Property and Conflict of Laws: The Basel Resolution of the Institute of International Law. International Journal of Cultural Property, Vol. 6., Issue 2.

Kisfaludi András [2006]: Fenntartható-e a dologi jog egyediségének elve? Polgári Jogi Kodifikáció, 8. évf., 6. sz.

Menyhárd Attila [2002]: Észrevételek és javaslatok az új Polgári Törvénykönyv dologi jogi koncepciójának kiegészítéséhez. Polgári Jogi Kodifikáció, 4. évf., 5-6. sz.

Menyhárd Attila [2013]: Dologi jog. ELTE Eötvös Kiadó, Budapest.

Müller, Markus M. [1998]: Cultural Heritage Protection: Legitimacy, Property, and Functionalism. International Journal of Cultural Property, Vol. 7., Issue 2.

Pecoraro, Thomas W. [1990]: Choice of Law in Litigation to Recover National Cultural Property: Efforts at Harmonization in Private International Law. Virginia Journal of International Law, Vol. 31., No. 1.

Prott, Lyndel V. - O'Keefe, Patrick J. [1992]: Cultural Heritage or Cultural Property. International Journal of Cultural Property, Vol. 1., Issue 2.

Reddy, Vinay [2001]: Common Law Conflict of Laws Rules and the Protection of Cultural Heritage: A Conflict Between the Two? Flinders Journal of Law Reform, Vol. 5., No. 2.

Reyhan, Patricia Youngblood [2001]: A Chaotic Palette: Conflict of Laws in Litigation Between Original Owners and Good-Faith Purchasers of Stolen Art. Duke Law Journal, Vol. 50., No. 4.

Roodt, Christa [2015]: Private International Law, Art and Cultural Heritage. Edward Elgar Publishing, UK.

Rotherham, Craig [1998]: Conceptions of Property in Common Law Discourse. Legal Studies, Vol. 18., No. 1.

Saltarelli, Angela [2018]: Restitution of Looted Art in Europe: Few Cases, Many Obstacles. Revista la Propiedad Inmaterial, Vol. 25.

Serák István [2007]: Átkelök a dolog-fogalom határain - a jogirodalom szemszögéböl. Iustum Aequum Salutare, III. évf., 4. sz.

Shyllon, Folarin [2003]: Private Law Beyond Markets for Goods and Services: The Example of Cultural Objects. Uniform Law Review, Vol. 8., No. 1-2.

Symeonides, Symeon C. [2005]: A Choice-of-Law Rule for Conflicts Involving Stolen Cultural Property. Vanderbilt Journal of Transnational Law, Vol. 38., No. 4.

Szabó Sarolta [2014]: A kulturális javakkal kapcsolatos restitúciós perek és a külföldi állammal szembeni végrehajtás: a Chabad v. Orosz Föderáció ügy tanulságai. In: Fekete Balázs - Horváthy Balázs - Kreisz Brigitta (szerk.): A világ mi magunk vagyunk... Liber Amicorum Imre Vörös. HVG-ORAC, Budapest. 
Szabó Sarolta [2016]: A kulturális javak (és a lopott dolgok) speciális védelme az új nemzetközi magánjogi törvényben. In: Berke Barna - Nemessányi Zoltán (szerk.): Azúj nemzetközi magánjogi törvény alapjai. Kodifikációs előtanulmányok. HVG Orac, Budapest.

Szabó Sarolta [2018]: Az új nemzetközi magánjogi törvény egyes általános részi kérdéseiről. Jogtudományi Közlöny, 73. évf., 11. sz.

Vadász Vanda [2017]: A Seuso eset tanulságai a jogellenesen külföldre vitt kulturális javak visszaszolgáltatása kapcsán. Magyar Jog, 64. évf., 1. sz.

Vadász Vanda [2020]: Az eredeti tulajdonos és a jóhiszemü vevő helyzete a kulturális javak visszaszolgáltatását célzó perekben. Iustum Aequum Salutare, megjelenés alatt.

Vékás Lajos [2016]: A törvény szerkezetéről és néhány általános részi kérdésről. In: Berke Barna - Nemessányi Zoltán (szerk.): Az új nemzetközi magánjogi törvény alapjai. Kodifikációs előtanulmányok. HVG Orac, Budapest.

Wantuch-Thole, Mara [2015]: Cultural Property in Cross-Border Litigation. Turning Rights into Claims. De Gruyter, Berlin.

Weber, Marc [2006]: New Swiss Law on Cultural Property. International Journal of Cultural Property, Vol. 13., Issue 1.

Ziegler, Tamás Dezsö - Vadász, Vanda - Szabó, Sarolta [2017/2018]: The New Hungarian Private International Law Code - A Mixture of Modern and Traditional Solutions. Yearbook of Private International Law, Vol. XIX., 2017/2018.

\section{Abstract of the Article}

\section{The law governing cultural property disputes in the Hungarian legal system}

VANDA VADÁSZ

This article considers the conflict-of-law rules for cultural goods, which have been taken and unlawfully removed abroad. First we analyze the sources of the Hungarian legal system, then we examine the relevant general institutions and special choice of law principles introduced by the Private International Law Act of 2017. 